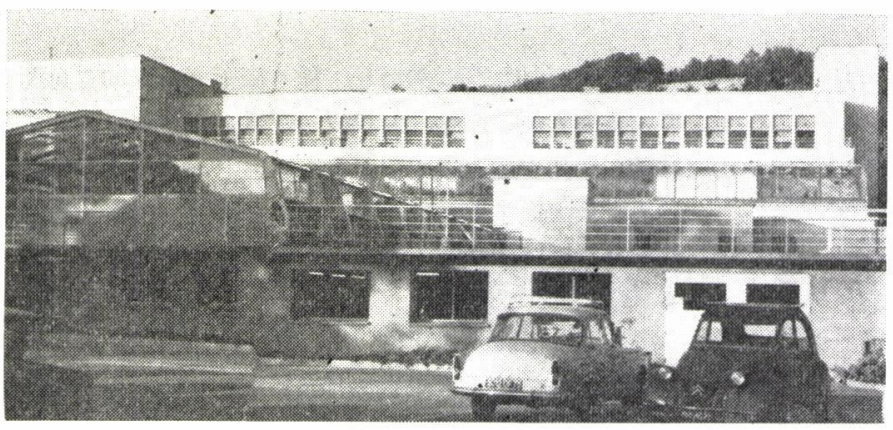

図 1 Phytotron の全景

\title{
Gif Phytotron*
}

自然光線室を正面からみたもの, 左側の温蜜はスーパー温室（禣助温室）

\section{むえがき}

フランスの Gif-sur-Yvette のファイトトロン(図1) については、これまでにも多くの日本の科学者が訪問さ れ, また先方の研究所からもシュワール所長はじめ, 二 ッチ副所長（図 2 ）, 原田宏氏などが来日され，いろい ろの機会に紹介されてきたが，phytotron の設計の参考 になるよらな諸資料の発表されたものは，市まり見あた らない，その理由の 1 つは，汪とえぞ完成を目前にして 爆発事故が起こり，その後改修されて完全に動き出した のは昨年の 9 月からということも，その大きな原因であ ったろろ。

筆者は，昨年 10 月下旬，パリの $\mathrm{OECD}$ 会議に出席の 機会に, パリ郊外の Gif-sur-Yvette にある国立つ? イトトロン研究所を訪間した. 終日, 原田氏の案内でフ ル運転を開始したばかりの phytotron をみせてもらっ たので，筆者の知り光た限りの資料を御紹介して大方の 参考に供したいと思う。

\section{1. 今日までの経緯}

現所長のシュアール氏が, 米国 Pasadena の phytotron の3 倍ぐらいのものを作りたいと政府に話をもち込んだ ところ, 1955 年に政府がこれを認め, 1956 年から工事 に着手した。1958 年に建物と実験室, phytotron の外 廓ができたので，早速 conditioner の試験を開始し， 1959 年と 60 年の両年の夏冬に自然光線室と人工光線室 のモデルについて試験を行ない，その試験結果にもとづ いて 1961 年, 62 年に全部の配管を完了し, 最後の仕 上げを急いでいたところ，1963 年 2 月 18 日に，人工 光線室第 4 室の叙装工事中, ピストル式噴射㙦装器の可 燃性ソルベントに引火, 大爆発を起こし, 死者 1 名, 12 の人工光線室のランプ, 自然光線室のガラスは全部破損 し，機械もこわれたということである。この爆発は裁判

* Heihachiro Miyayama : The Phytotron of Gif-sur-Yvette France.

** Science Supervisor, Buraeu of Higher Education and Science, Ministry of Education, Tokyo.
事件になっているため, 7 月までは全然手がつけられ ず，その後，機械の作り直 しを始めた。 人工光線室は 1964 年中に改修が終り, 自然光線室も 1965 年はじ めに復旧が終り，9月以降 運転を開始したといらこと であった.したがって、こ の研究所は着工以来約 10

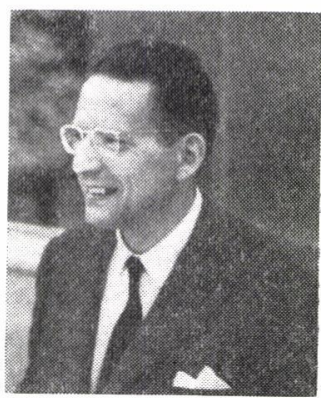

図 2 NiTCH 副所長 (1962.9, 来日の折撮影したもの) 年間，溧とんど phytotron の建設に終始して今日に至ったといらことがでさよう。 その間に投じられた経費は，邦貨に換算して約 30 億円 といわれている。な执, 付属のスーパー温室, 研究室, 実験室の桩張計画が進められているが，完成までには2。 カ年を要するということであった。

\section{Phytotron 研究所の建物}

ファイトトロン研究所は 3 階建の建物で， 1 階は主之: して機珹室が占め, 并のほか作場, 宿直室, 園丁控 室, ストックルーム, 組織培養室, 凍結乾燥室, アベナテ スト室, クロマトグラフィーや電気泳動などの測定室, さ らにイオン交換水や培養液のタンクもあり各室へ配管さ れている、 2 階が phytotron に当てられ, 準備室, 管 理室などがある。 3 階は, 所長, 副所長, 事務長の部屋 をはじめ, 所員の研究室, 実験室, 図書室などからなっ ている.

次に, 各階の平面図を示すと, 図 3 , 図 4 , 因 5 のと. おりである。

図 4 亿示す 2 階が phytotron の平面図になるわけで あるが，事務室側からみて，廊下をはさんで左側が人工 光線室, 右側が自然光線室である(図6).人工光線室 は， 1 室あたり $3 \times 3.8 \mathrm{~m}$ の面積をもつものが 12 室め り, 自然光線室は, $6.5 \times 5.5 \mathrm{~m}$ の部屋が 8 つ市, 手 前から A, B, C, D, E, F, G, H と呼称されている.

研究所の建物を側面からみた図が，図７（図４のa， 断面図）に示したものである.

Environ. Cont. in Biol. (生物環境調節) 


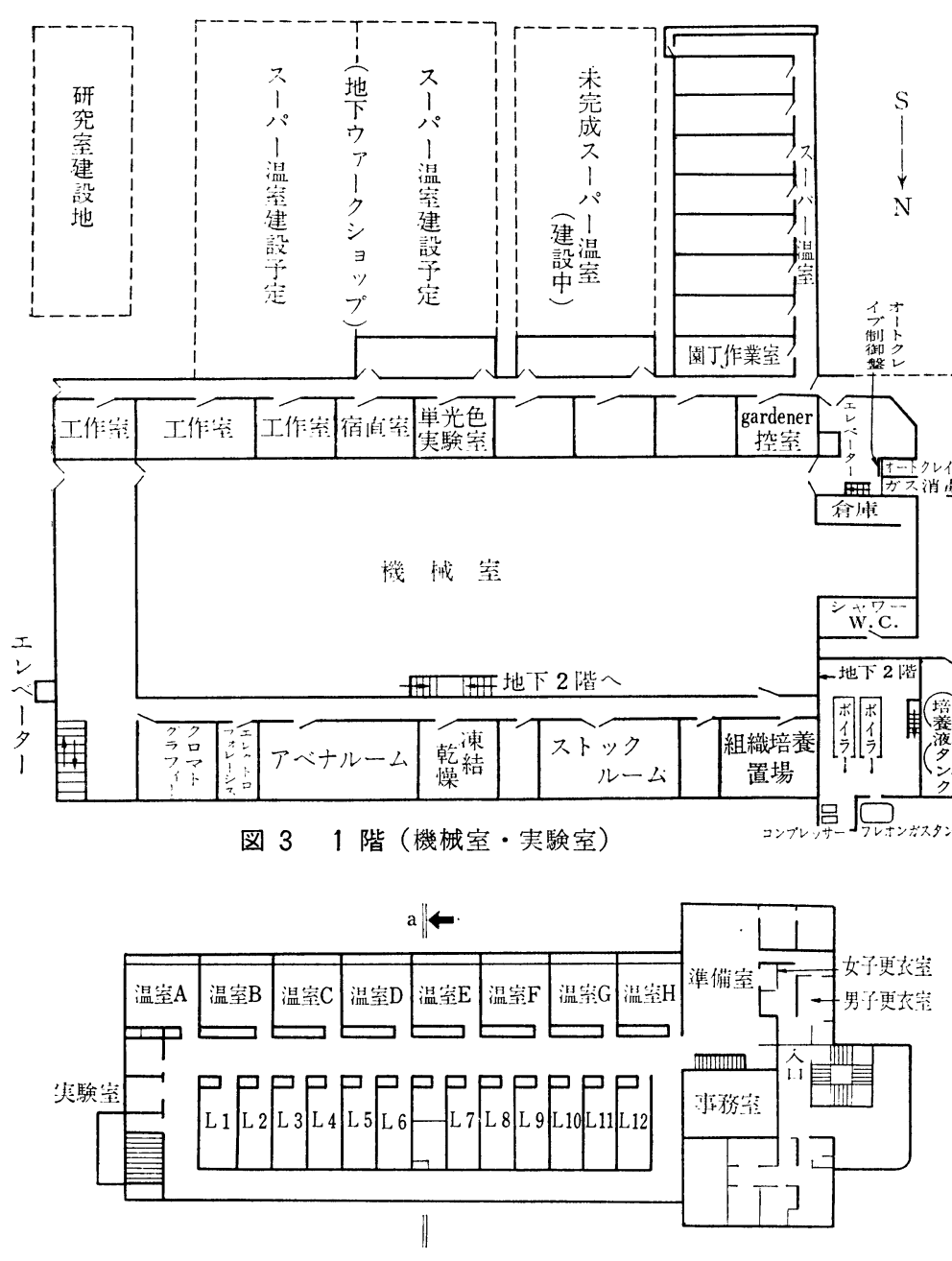

図42 階平面図

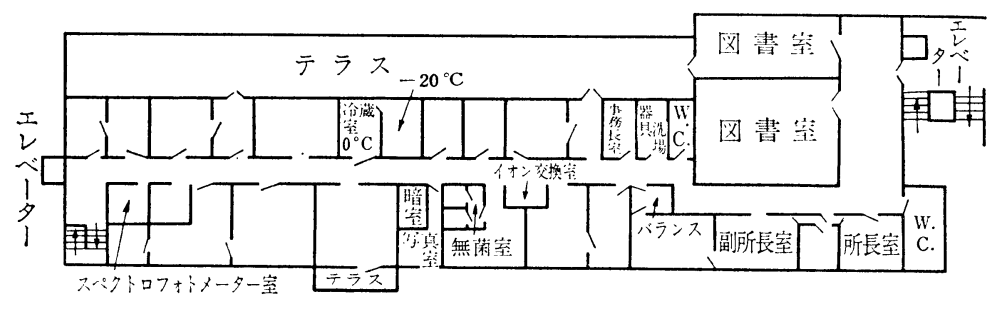

図 53 階実験室

テラスの下が phytotron の人工光線室になる. tronの各部屋の温度設定条 件を決めて, あらかじめ所 員に通知すること汇なって いる、表 2 は，たまたま筆 者が訪れた 10 月の設定条 件である、 1 カ月前に予告 される。

フランスの phytotron は, 温度の最低は人工照明 室の場合 $-10^{\circ} \mathrm{C}$, 温室の場 合は $+6^{\circ} \mathrm{C}$ で, 最高は +40 $\sim 45^{\circ} \mathrm{C}$ である. すなわち, 以上の上うな制限内では, 地球上のあらゆる気候を造 り出すことができる，実験 に必要な気候をうるには, 部屋のプログラムを色彩標 識で略号化されている予定 表によって，手押車の上 の植物を移動させるだけで よい.すなわち, Pasadena 方式によっているわけであ る.

\section{4. 室内の空気調節}

室内の空気謂節について は, 温室 (自然光線室, 図 8）〕人工照明室もすべて 同一の方式にしたがって換 気されている，設定ど拈り の温度と湿度をもった架気 は, 人工気象装置を出ると， 人工照明室の場合は， 1 時 間女たり平均 80 回，温室 の場合は 120 回の更新を確 実にするように速やかに部 屋の中に送りこまれる。

高さ $70 \sim 80 \mathrm{~cm}$ の弛緩 箱には, 平均穿孔率 0.0197 \%の割合で孔をあけた薄い 金属板の蓋がついている. 横腹にも二重の譬のついた

\section{Phytotron 研究所の温湿度設定条件}

Phytotron 飞打沙る温湿度設定条件は，その立地自然 環境と研究目的によって設定されるわけであるが，この 研究所比打る設計上の capacity は，表1亿示すと抒 りである.

な挍，この研究所では，每月，その月に拈ける phyto-
直径 $10 \mathrm{~m} / \mathrm{m}$ の孔をるつこれらの薄い金属板が長方形に 配列され，これが部屋の床にるなっている。この小さな 孔が，植物を載せた手押車の移動を妨げるようなことは まったくない，この箱は，空気循環の速度を弱め，エア 一ポケットをなくすためのものである。吹出速度は，箱 の入口で落ちてしまう。すなわち，らがった孔を通ると 
表 1 フランス Phytotron 研究所における設 計上の温湿度条件

1)人工光線室

\begin{tabular}{|c|c|c|c|c|c|}
\hline \multirow{2}{*}{ 部屋 } & \multicolumn{2}{|c|}{ 温 } & 度 & \multirow{2}{*}{$\begin{array}{r}\text { 湿 } \\
\text { 最低 }\end{array}$} & \multirow{2}{*}{$\begin{array}{l}\text { 度 } \\
\text { 最高 }\end{array}$} \\
\hline & 最低 & 平均 & 最高 & & \\
\hline 1 & $-10^{\circ} \mathrm{C}$ & $-6^{\circ} \mathrm{C}$ & $0^{\circ} \mathrm{C}$ & 調節 & せず \\
\hline 2 & -4 & +1 & +5 & , & \\
\hline 3 & +1 & 5 & 10 & , & \\
\hline 4 & 7 & 9 & 12 & $5^{\circ}$ (露点) & $90 \%$ H. R. \\
\hline 5 & 8 & 12 & 22 & $5^{\circ}(\prime \prime)$ & 90 \\
\hline 6 & 11 & 15 & 19 & $5^{\circ}(" \prime)$ & 80 \\
\hline 7 & 14 & 18 & 24 & $7^{\circ}(\prime \prime)$ & 80 \\
\hline 8 & 17 & 21 & 28 & $7^{\circ}(\prime \prime)$ & 70 \\
\hline 9 & 17 & 24 & 28 & 50 & 90 \\
\hline 10 & 22 & 27 & 31 & 50 & 80 \\
\hline 11 & 25 & 30 & 40 & $5^{\circ}(\prime \prime)$ & 70 \\
\hline 12 & 25 & 30 & 40 & 50 & 100 \\
\hline
\end{tabular}

2) 自然光線室

\begin{tabular}{|c|c|c|c|c|c|c|c|c|}
\hline $\begin{array}{l}\text { 部 } \\
\text { 屋 } \\
\end{array}$ & $\begin{array}{l}\text { 夜 } \\
\text { 最低 }\end{array}$ & $\begin{array}{l}\text { 間温 } \\
\text { 平均 }\end{array}$ & $\begin{array}{l}\text { 度 } \\
\text { 最高 } \\
\end{array}$ & $\begin{array}{c}\text { 昼 } \\
\text { 最低 } \\
\end{array}$ & $\begin{array}{l}\text { 間温目 } \\
\text { 平均 }\end{array}$ & $\begin{array}{l}\text { 度 } \\
\text { 最高 }\end{array}$ & $\begin{array}{r}\text { 湿 } \\
\text { 最低 } \\
\end{array}$ & $\begin{array}{l}\text { 度 } \\
\text { 最高 }\end{array}$ \\
\hline A & $\begin{array}{r}{ }^{\circ} \mathrm{C} \\
+6\end{array}$ & $\begin{array}{r}{ }^{\circ} \mathrm{C} \\
+8\end{array}$ & $\begin{array}{r}{ }^{\circ} \mathrm{C} \\
+13\end{array}$ & $\begin{array}{r}{ }^{\circ} \mathrm{C} \\
+9\end{array}$ & $\begin{array}{r}{ }^{\circ} \mathrm{C} \\
+12\end{array}$ & $\begin{array}{r}{ }^{\circ} \mathrm{C} \\
+16\end{array}$ & $\begin{array}{r}\text { P.R. } \\
5^{\circ}\end{array}$ & $\begin{array}{l}\text { H. R. } \\
90 \%\end{array}$ \\
\hline B & 7 & 10 & 16 & 11 & 15 & 19 & $5^{\circ}$ & 90 \\
\hline $\mathrm{C}$ & 9 & 12 & 19 & 14 & 18 & 22 & $6^{\circ}$ & 80 \\
\hline $\mathrm{D}$ & 11 & 14 & 22 & 16 & 21 & 30 & $7^{\circ}$ & 90 \\
\hline $\mathrm{E}$ & 13 & 17 & 25 & 20 & 24 & 28 & $7^{\circ}$ & 80 \\
\hline $\mathrm{F}$ & 16 & 20 & 28 & 23 & 27 & 31 & $7^{\circ}$ & 80 \\
\hline $\mathrm{G}$ & 19 & 25 & 31 & 26 & 30 & 40 & $50 \%$ & 90 \\
\hline $\mathrm{H}$ & 19 & 25 & 31 & 26 & 30 & 40 & $5^{\circ}$ & 70 \\
\hline
\end{tabular}

表 2 10月における温度および日長の設定条件

\begin{tabular}{|c|c|c|c|c|c|c|}
\hline \multicolumn{4}{|c|}{ 自 然 光 線 室 } & \multicolumn{3}{|c|}{ 人工光線室 } \\
\hline 部屋 & $\begin{array}{c}\text { 温 }^{-} \\
\text {是 }\end{array}$ & $\begin{array}{l}\text { 度 } \\
\text { 夜 }\end{array}$ & 日長 & 部屋 & & $\begin{array}{l}\text { 度 } \\
\text { 夜 }\end{array}$ \\
\hline A & $12^{\circ} \mathrm{C}$ & $12^{\circ} \mathrm{C}$ & $16 \mathrm{~h}$ & 1 & $0^{\circ} \mathrm{C}$ & $0^{\circ} \mathrm{C}$ \\
\hline B & 17 & 17 & 16 & 2 & 2 & 2 \\
\hline $\mathrm{C}$ & 22 & 22 & 18 & 3 & 7 & 7 \\
\hline D & 22 & 22 & 9 & 4 & 12 & 12 \\
\hline $\mathrm{E}$ & 24 & 18 & 9 & 5 & 22 & 12 \\
\hline $\mathrm{F}$ & 24 & 18 & 18 & 6 & 17 & 17 \\
\hline G & 27 & 27 & 18 & 7 & 19 & 19 \\
\hline $\mathrm{H}$ & 32 & 32 & 16 & 8 & 27 & 17 \\
\hline & & & & 9 & 22 & 22 \\
\hline & & & & 10 & 27 & 27 \\
\hline & & & & 11 & 32 & 32 \\
\hline
\end{tabular}

$54 \quad(54)$

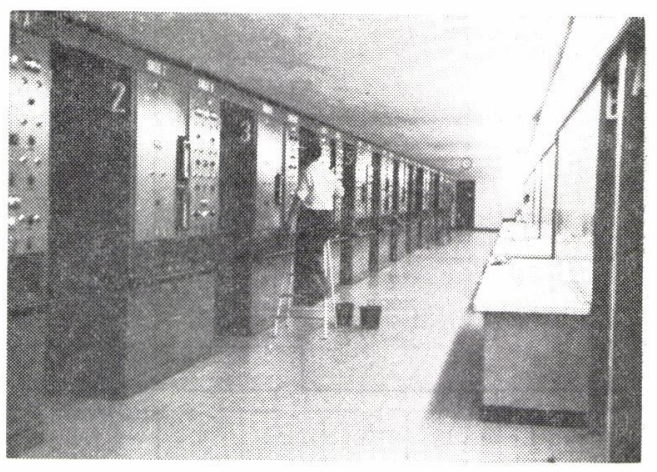

図 6 向って左が人工光線室, 右が自然光線室 ( 2 階)

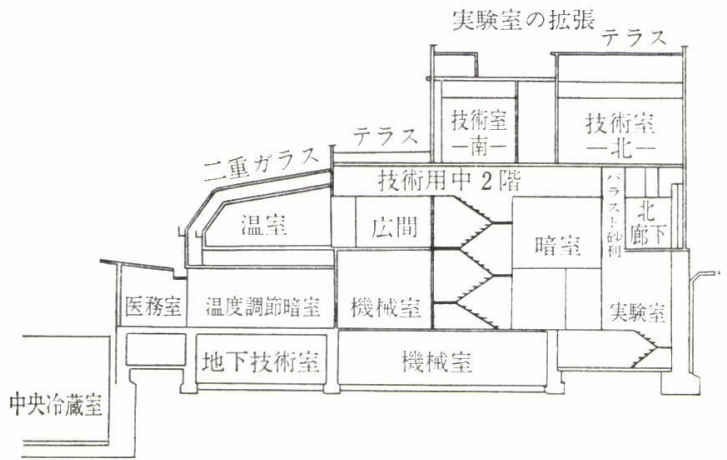

図 7 研究所の断面図

(四 4のaのところでったもの)

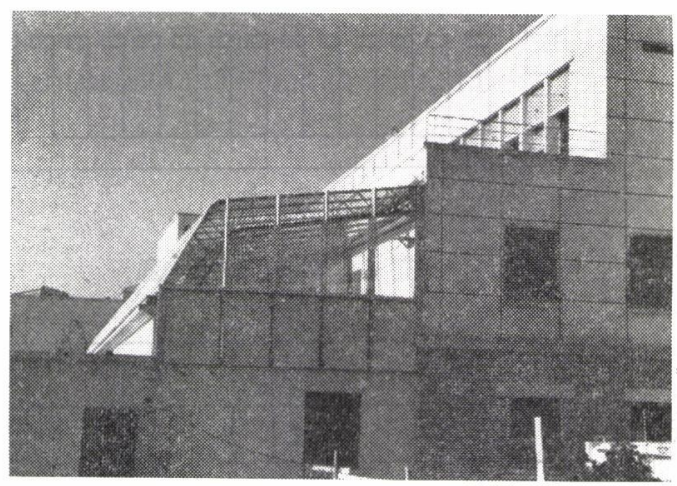

図 8 研究所の側面, 見えているのは自然光線室 きに生ずる風压のロスに応じて軽い一定の超過圧力を維 持する，室内の床面 (図 9), すなわら孔のレベルにお。 ける空気の速度はおよそ $3 \sim 4.5 \mathrm{~m} / \mathrm{s}$ である. しかし床 から $20 \sim 30 \mathrm{~cm}$ 以上の高さでは, 風といち感じはなく なってしまう。部屋の中の空気は, 秒速 $10 \sim 20 \mathrm{~cm}$ の 割合で一様に上昇するが，植物の葉を乱したり動かした りするようなことはない、いくつかの部屋を例にとっ て，いろいろのレベルにおける空気速度を調べてみた が，平均变動が 10\%を越えることはほとんどないとい らことである(表 3 ).

空気流れの上年運動は, 吸込口の横引運動によって恒 Environ. Cont. in Biol. (生物環境調節) 
表 3 各高さごとの空気の平均速度

\begin{tabular}{|c|c|c|c|c|}
\hline \multirow{2}{*}{ 部 屋 } & & あき 金 属 & 5 の 高 & \\
\hline & $0.50 \mathrm{~m}$ & $1.00 \mathrm{~m}$ & $1.50 \mathrm{~m}$ & $1.90 \mathrm{~m}$ \\
\hline 5 & $0.167 \pm 8.4 \%$ & $0.136 \pm 8.8 \%$ & $0.126 \pm 6.3 \%$ & $0.109 \pm 6.4 \%$ \\
\hline 6 & $0.195 \pm 6.7 \%$ & $0.166 \pm 6.7 \%$ & $0.113 \pm 5.3 \%$ & $0.084 \pm 4.8 \%$ \\
\hline 7 & $0.217 \pm 7.4 \%$ & $0.181 \pm 7.7 \%$ & $0.137 \pm 7.3 \%$ & $0.098 \pm 5.1 \%$ \\
\hline 8 & $0.204 \pm 7.8 \%$ & $0.201 \pm 7.5 \%$ & $0.151 \pm 5.3 \%$ & $0.092 \pm 4.4 \%$ \\
\hline 9 & $0.239 \pm 5.9 \%$ & $0.219 \pm 6.9 \%$ & $0.162 \pm 5.3 \%$ & $0.107 \pm 3.8 \%$ \\
\hline 10 & $0.234 \pm 6.9 \%$ & $0.200 \pm 7.0 \%$ & $0.169 \pm 5.3 \%$ & $0.118 \pm 4.3 \%$ \\
\hline 11 & $0.199 \pm 6.5 \%$ & $0.185 \pm 5.4 \%$ & $0.135 \pm 5.2 \%$ & $0.090 \pm 5.6 \%$ \\
\hline 12 & $0.253 \pm 6.7 \%$ & $0.202 \pm 5.5 \%$ & $0.140 \pm 6.4 \%$ & $0.085 \pm 4.7 \%$ \\
\hline A & $0.151 \pm 9.3 \%$ & $0.176 \pm 10.8 \%$ & $0.105 \pm 12.4 \%$ & $0.141 \pm 9.9 \%$ \\
\hline B & $0.132 \pm 10.6 \%$ & $0.150 \pm 8.7 \%$ & $0.138 \pm 8.8 \%$ & $0.097 \pm 7.2 \%$ \\
\hline $\mathrm{D}$ & $0.128 \pm 8.6 \%$ & $0.101 \pm 10.9 \%$ & $0.077 \pm 14.3 \%$ & $0.094 \pm 8.5 \%$ \\
\hline $\begin{array}{c}\text { 平均值 } \\
\text { 人士照明室 }\end{array}$ & $0.213 \mathrm{~m} / \mathrm{s}$ & $0.186 \mathrm{~m} / \mathrm{s}$ & $0.141 \mathrm{~m} / \mathrm{s}$ & $0.098 \mathrm{~m} / \mathrm{s}$ \\
\hline 室 & $0.137 \mathrm{~m} / \mathrm{s}$ & $0.142 \mathrm{~m} / \mathrm{s}$ & $0.107 \mathrm{~m} / \mathrm{s}$ & $0.111 \mathrm{~m} / \mathrm{s}$ \\
\hline
\end{tabular}

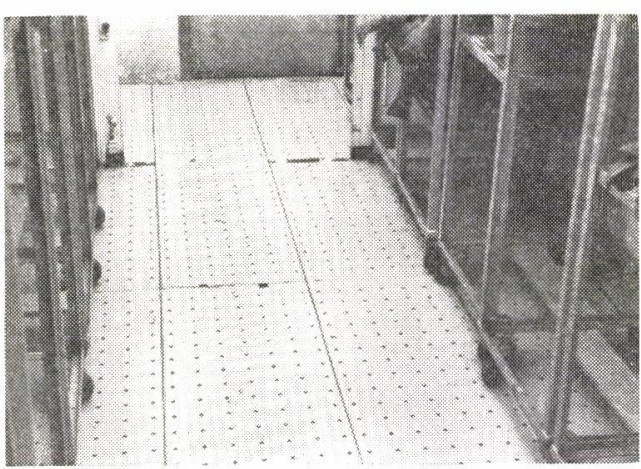

図 9 穴のあいた床板

(ここから調節された空気老吹出至)

表 4 吸込口の入口における空気の平均速度 (単位 $\mathrm{mm} / \mathrm{s}$, 標準偏差を。で付就する)

\begin{tabular}{|c|c|c|c|}
\hline 部 & 屋 & 西 側 吸込口 & 東 側 吸込口 \\
\hline & 5 & $2.17 \pm 3.7 \%$ & $2.73 \pm 4.0 \%$ \\
\hline & 6 & $2.66 \pm 3.4 \%$ & $2.70 \pm 4.1 \%$ \\
\hline & 7 & $3.20 \pm 2.8 \%$ & $3.77 \pm 4.5 \%$ \\
\hline & 8 & $1.93 \pm 3.6 \%$ & $2.86 \pm 3.2 \%$ \\
\hline & 9 & $2.81 \pm 3.2 \%$ & $2.83 \pm 3.8 \%$ \\
\hline & 10 & $3.51 \pm 3.4 \%$ & $3.16 \pm 3.8 \%$ \\
\hline & 11 & $2.87 \pm 4.2 \%$ & $2.74 \pm 3.3 \%$ \\
\hline & 12 & $2.42 \pm 3.5 \%$ & $3.76 \pm 3.7 \%$ \\
\hline 温 & 室 A & $1.01 \pm 2 \%$ & $1.20 \pm 0$ \\
\hline & 室 B & $5.00 \pm 0$ & $4.72 \pm 1.3 \%$ \\
\hline & & $1.08 \pm 1.9 \%$ & $2.28 \pm 2.6 \%$ \\
\hline
\end{tabular}

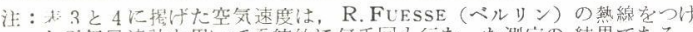

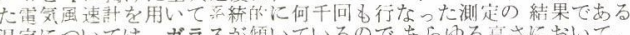

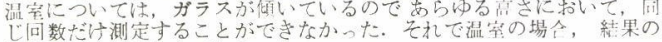
䊑度はいくぶえ和bてしまった。

Vol. 4, No. 1 (1966)

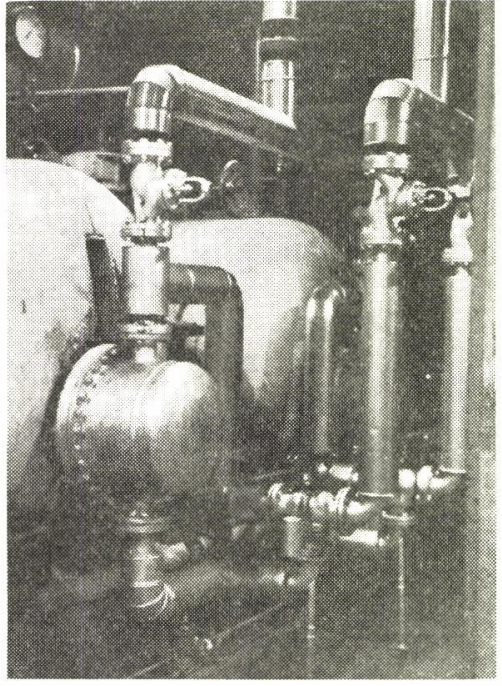

図 10 加熱装置（1階機械空）

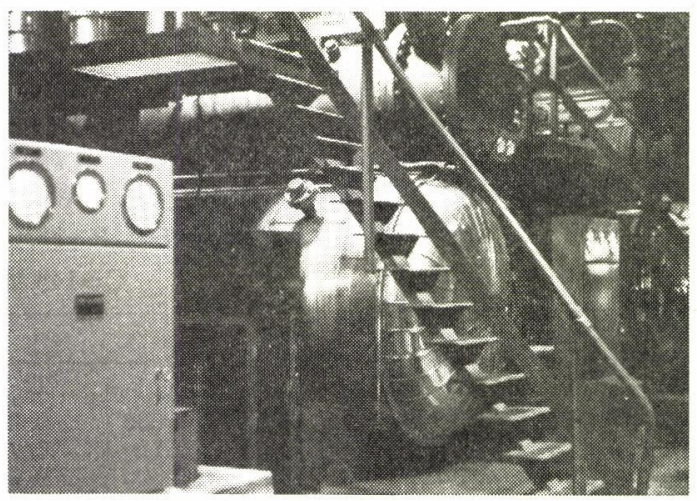

図 11 冷却装置 ( 1 階機械室) 

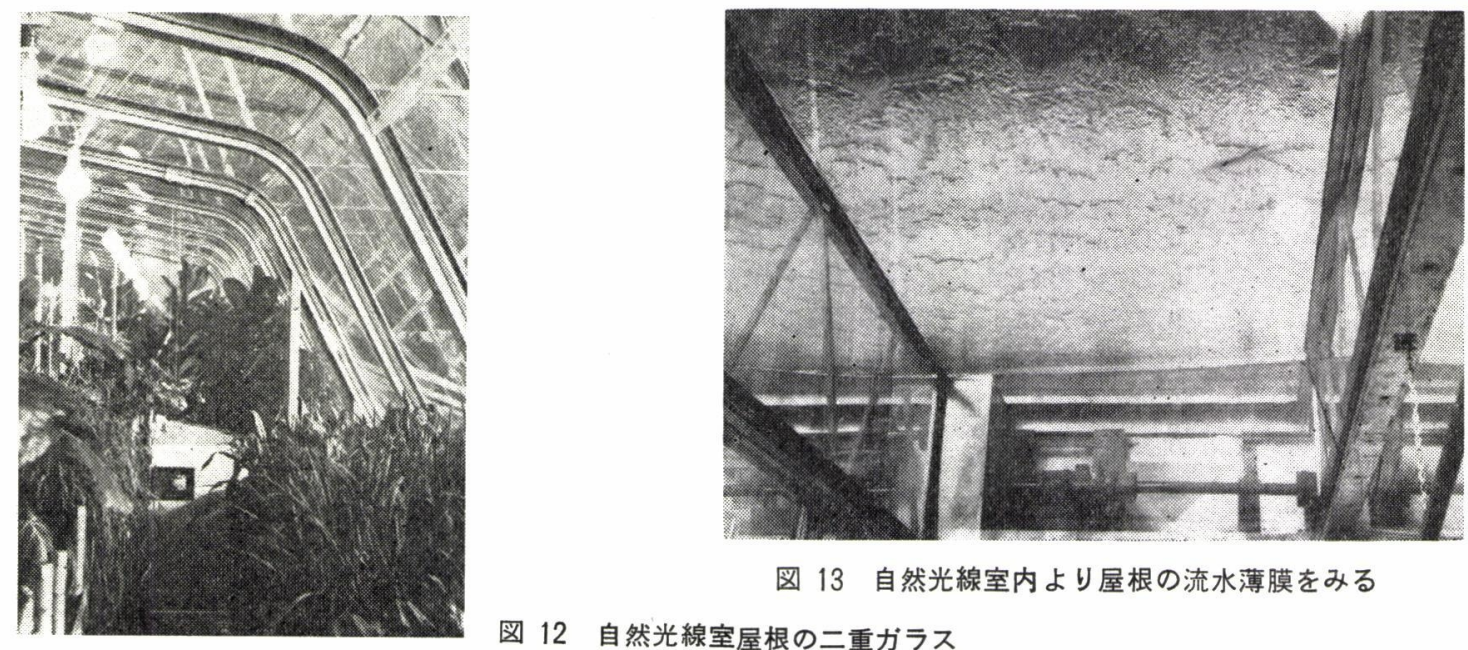

図 13 自然光線室内より屋根の流水薄膜をみる

図 12 自然光線室屋根の二重ガラス

表 5 \% 人気象装置の特性

\begin{tabular}{|c|c|c|c|c|c|c|c|c|c|c|}
\hline \multirow{2}{*}{ 部 屋 } & 送 & 機 & \multirow{2}{*}{$\begin{array}{l}\text { 冷却能力 } \\
\mathrm{FG} / \mathrm{hr}\end{array}$} & \multirow{2}{*}{$\begin{array}{c}\text { 暖房能力 } \\
\mathrm{kcal} / \mathrm{hr}\end{array}$} & \multirow{2}{*}{$\left|\begin{array}{c}\text { 冷却コイル } \\
\mathrm{kcal} / \mathrm{hr}\end{array}\right|$} & \multirow{2}{*}{$\begin{array}{l}\text { 加 湿 器 } \\
\text { kcal/hr }\end{array}$} & \multirow[b]{2}{*}{$\mathrm{FG} / \mathrm{hr}$} & \multirow{2}{*}{\multicolumn{2}{|c|}{$\begin{array}{c}\text { カテーヌ } \\
\text { 濃 } \\
\%^{\text {度 }}\end{array}$}} & \multirow{2}{*}{$\begin{array}{c}\text { 塩水温度 } \\
{ }^{\circ} \mathrm{C}\end{array}$} \\
\hline & 風量 $\mathrm{m}^{3} / \mathrm{hr}$ & 電動機 $\mathrm{kW}$ & & & & & & & & \\
\hline \multicolumn{11}{|c|}{ 1) 人工照明室 } \\
\hline 1 & 8,500 & 7.3 & - & - & - & - & 33,350 & \multicolumn{2}{|c|}{15} & -20 \\
\hline 2 & 7,470 & 7.3 & - & - & - & - & 29,340 & \multicolumn{2}{|c|}{15} & -20 \\
\hline 3 & 7,650 & 7.3 & - & - & - & - & 27,470 & \multicolumn{2}{|c|}{17} & -20 \\
\hline 4 & 7,700 & 2.9 & 29,700 & 15,800 & - & 18,400 & - & \multicolumn{2}{|c|}{-} & -2 \\
\hline 5 & 7,700 & 2.9 & 71,000 & 55.000 & - & 18,400 & - & \multicolumn{2}{|c|}{-} & -2 \\
\hline 6 & 7,940 & 2.9 & 25,000 & 34,200 & 18,400 & - & - & \multicolumn{2}{|c|}{-} & -2 \\
\hline 7 & 8,140 & 3.7 & 41,200 & 35,500 & 18,400 & - & - & \multicolumn{2}{|c|}{-} & -2 \\
\hline \multirow[t]{2}{*}{8} & 8,200 & 7.3 & 19,200 & $\mathrm{P}=28,300$ & - & - & 76,200 & \multirow{2}{*}{\multicolumn{2}{|c|}{$18 \quad 27$}} & -2 \\
\hline & & & & $\mathrm{C}=55,800$ & & & & & & \\
\hline 9 & 8,320 & 3 & 51,000 & 36,100 & 18,400 & - & - & \multicolumn{2}{|c|}{-} & -2 \\
\hline 10 & 8,430 & 3 & 37,750 & 41,750 & 18,400 & - & - & \multicolumn{2}{|c|}{ - } & -2 \\
\hline \multirow[t]{2}{*}{11} & 8,850 & 7.3 & 21,900 & $\mathrm{P}=49,000$ & - & - & 71,900 & \multirow{2}{*}{\multicolumn{2}{|c|}{30}} & -2 \\
\hline & & & & $C=119,500$ & & & & & & \\
\hline 12 & 9,020 & 3.7 & 73,000 & 75,000 & 18,400 & - & - & \multicolumn{2}{|c|}{ - } & -2 \\
\hline \multicolumn{11}{|c|}{ 2) 温室 } \\
\hline A & 11,500 & 4. 4 & 36,000 & 34,400 & 33,000 & - & - & \multicolumn{2}{|c|}{ - } & -2 \\
\hline B & 11,700 & 4. 4 & 50,000 & 42,000 & 33,000 & 33,000 & - & \multicolumn{2}{|c|}{ - } & -2 \\
\hline $\mathrm{C}$ & 11,900 & 4. 4 & 48,600 & 45,000 & 33,000 & - & - & \multicolumn{2}{|c|}{-} & -2 \\
\hline $\mathrm{D}$ & 14,000 & 5.8 & 65,000 & 93,000 & 33,000 & - & - & & - & -2 \\
\hline $\mathrm{E}$ & 12,200 & 4. 4 & 50,300 & 50,300 & 33,000 & - & - & & - & -2 \\
\hline $\mathrm{F}$ & 12,400 & 4.4 & 50,300 & 56,700 & 33,000 & - & - & & - & -2 \\
\hline G & 13,600 & 3.7 & 96,000 & 106,800 & - & 33,000 & - & & & -2 \\
\hline $\mathrm{H}$ & 12,750 & 7.3 & 46,000 & $\begin{array}{r}P=38,600 \\
C=143,000\end{array}$ & - & & 160,000 & 30 & 42 & -2 \\
\hline 3) 二 & 重 ガ ラ & ス 張 & & & & & & & & \\
\hline & & A & B & $\mathrm{C}$ & $\mathrm{D}$ & $\mathrm{E}$ & $\mathrm{F}$ & & & $\mathrm{H}$ \\
\hline 送風機 & $\begin{array}{l}\text { 風量 } \mathrm{m}^{3} / \mathrm{h} \\
\text { 電動機 } \mathrm{kW}\end{array}$ & & $\begin{array}{l}4, \\
1 .\end{array}$ & $\begin{array}{l}3,800 \\
0.7\end{array}$ & $\begin{array}{l}5,300 \\
1.4\end{array}$ & $\begin{array}{l}4,530 \\
1.1\end{array}$ & $\begin{array}{l}4,960 \\
1.1\end{array}$ & & 050 & $\begin{array}{l}3,300 \\
1,1\end{array}$ \\
\hline 暖房能 & 力 $\mathrm{cal} / \mathrm{h}$ & & 10 , & 9,900 & 19,800 & 11,900 & 13,000 & & 8,600 & 7,900 \\
\hline
\end{tabular}

$\mathrm{P}$ =予熱用加熱, $\mathrm{C}=$ 補助加愁, $\mathrm{B}$ 系列は特に蒸気の注入まなは除湿器ととるに作動する.

FG : Frigorie 冷谏能力の単位で Ref Ton あるいは kcal との関係未調直.

$56 \quad(56)$

Environ. Cont. in Biol. (生物環境調節) 
常的に行なわれている.それは吸込口が部屋の上部の東, 西の側面にあるからである。吸込口に持ける速度は，温 度が一定の場合は時間の経過に関係なく不変で㟧るが, 表 4 に示すよ 5 に, 部屋によって $1 \sim 4 \mathrm{~m} / \mathrm{s}$ の範四内で 変化する。たたし，東側と西側の吸込口に上る吸込量は 調整器で変化させることができる。この調整器は, 吸込 口の吸込率を変化させるものである。

空気は吸込ダクトから送風機によって吸い出される。 送風機は, 人工気象装置（冷却装置, 加熱装置, 除湿器 からなる)（図 10，11）の中を通して，要求に応じてそ の温度や湿度を修正した後，空気を部屋汇送りか元す。 な祘送風機の吸込側近くに, 新しく補充されるほぼ 300 $\mathrm{m}^{3} / \mathrm{hr}$ の空気が導かれるようになっている。この補充分 は, 空気の改新, 戸の開閉や目張りの不備による空気の 漏洩に対する埋め合わせ，それと超過圧力のためのるの である.とくに超過圧力は, 外気の侵入を防ぐための配 虑によるものである。

人工気象装置の性能については, 特段の注意が払われ ている、たと党ば, 人工照明室の場合, 照明にどのよう な変動が起こっても, 室内のどの地点においても, 乾球

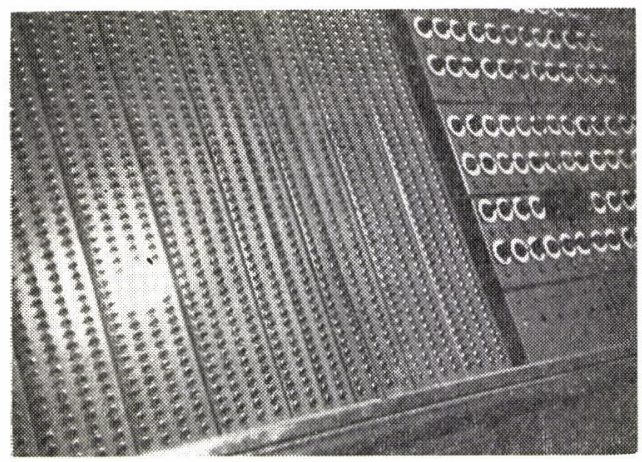

図 14 ランプ点滅の遠隔制御盤

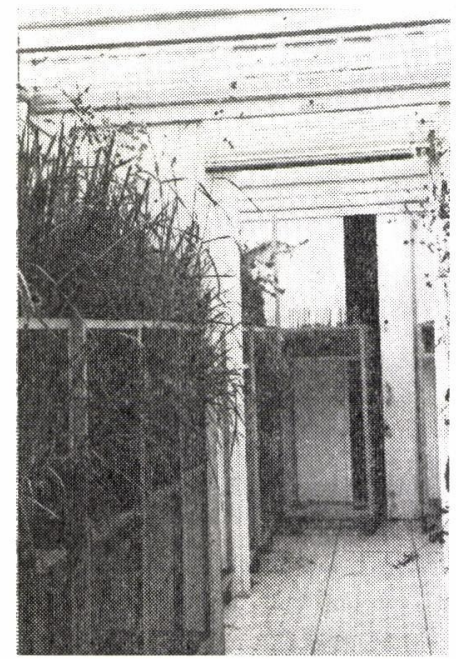

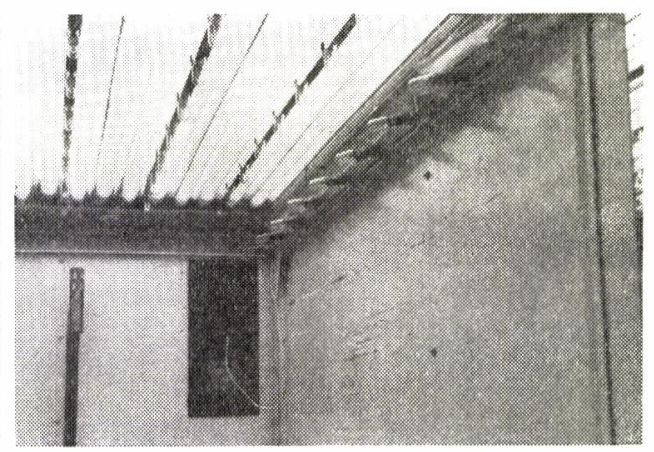

図16人工光線室上部

營光管の下に吸迄口あり, 有側の小ラ ンプは白熱灯 (低压)

4図 15 人工光線室の螢光管と白熱ランプ
温度で $\pm 0.1^{\circ} \mathrm{C}$, 湿球温度で $\pm 0.2^{\circ} \mathrm{C}$ の精度がえられ る、いうまですないが, ここにいう精度は空気の温度だ けについてである。刘象の性質によって变化する光線効 果はできる限り除去してめるという前提に立っての話で ある。

な报, 空気の条件を完全に変えた場合, 新しい調整に 落ちつくには約 1 時間を必要とする, 条件の変更は, 温 度と湿度と学別々か女るい愉時に, 部屋の条件変更の できる範囲内で, 空気湿度のダイヤグラムの 1 点から正 反対の点に移すことによって行なわれる。

温窒（自然光線窒）の場合には, 精度は若干劣る。外 の天候が安定しているときであれば，乾球温度で約土 $0.2^{\circ} \mathrm{C}$, 湿球温度で約 $\pm 0.3^{\circ} \mathrm{C}$ の精度であるが, 外の天 候が頻繁に飛来する雲によって変化する場合, フランス では主に太陽光線がひじょうに活動的になる春がそうで あるが, 乾球温度で $\pm 0.5^{\circ} \mathrm{C}$, 湿球温度で $\pm 0.7^{\circ} \mathrm{C}$ の 精度が党られている。そのかわりに, 極端な条件から, も5一方の極端な条件へ移行するのに必要な時間は, 人 工照明室の場合と同様 1 時間である。というのは，この 高精度は,すでに始まっている条件の変化を促進したり， 緩めたりする調節器（この目的のために，とくに考案さ れた外部の緩急ゾンデ）の利用によって兄られるように なった。

5. 室内空気の温度, 湿度調整の多様性

温度扔よび湿度について, 室内調整がひじょうに正確 に確保されるよ5になると, 外部からの影響を遮断する 必要が生じる、自然光線室では, このために温室に二重 ガラスを用いている(図 12)。二重ガラスの閒には, 絶 えず公内の空気より $5{ }^{\circ} \mathrm{C}$ 高い乾燥した空気が還流し、こ れで, 室内の内壁や, 外壁の外側に湿気が凝縮するのを 防いでいる(図 13).

また，外側のガラスの上を，できるだけ均一な薄膜に なるように, 噴第器でさ らなく噴きつけられた水 が流れている(1時間に $\left.10 \mathrm{~m}^{3}\right)$.この水膜は, い くつかの目的をもってい る. その1つは, 植物に とって無益であるばかり でなく室内空気の泠却と い5 余計な仕事を強制す る波長 $1,500 \mathrm{~m} \mu$ 以上の 非常に長い波長の太陽熱 光線が室内に侵透する割 合を引き下げる役割をる って打り，また，透明な 仕切壁を冷却して部屋の 


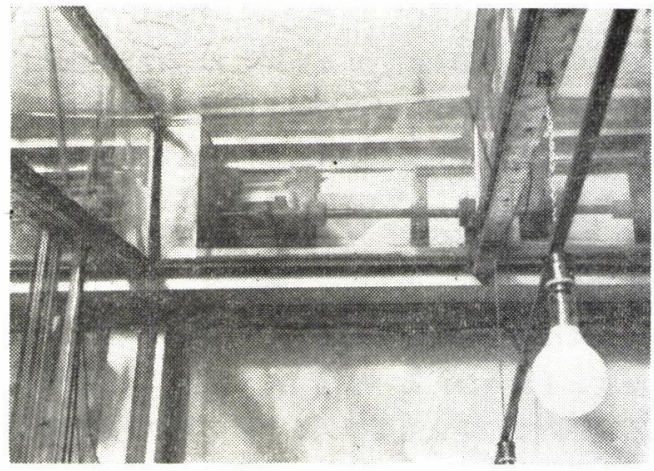

図 17 日長調節のための日覆シャッター

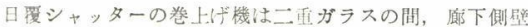

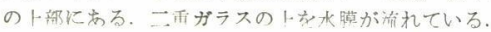

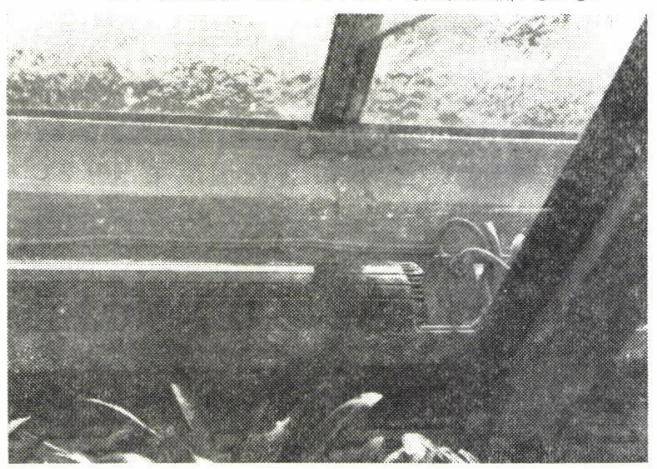

図 18 日長調節のための日覆シャッターを 巻き下したところ

これは二重ガラスの間に装置されている。

内部に熱を放射するのを防いでいる，このために，植物 の過熱が避けられる。さらにこの膜は, 散乱によって光 をよりよく配分し，ガラスを支兄ている小梁や桁，すな わち，小さな木材によって作られる影を半影の域につく り出している。

各人工気像調整装置の運転は, 速度を变觉ながら進え でいく 2 つ電動式調節器 (乾球温度と湿球温度) に上っ て制御されている。これらの調節器は, それぞれ適当な 直径をもった蝶型升を制御している5つのモーター（冷 却装置に 2 つ, 加熱装置に 2 つ, 除湿器または蒸気加湿

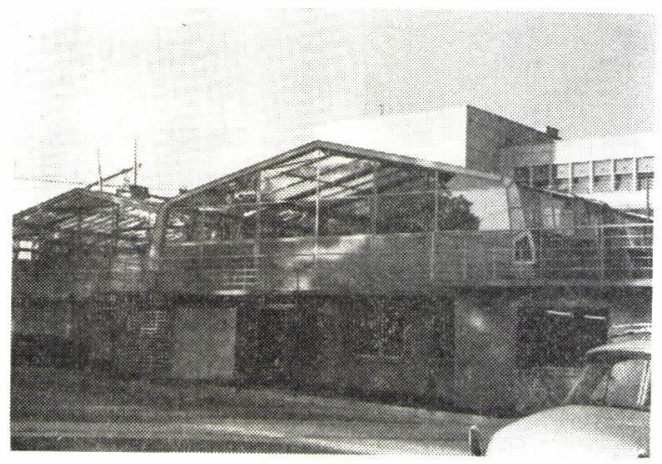

図 20 スーパー温室の側面（2 棟）

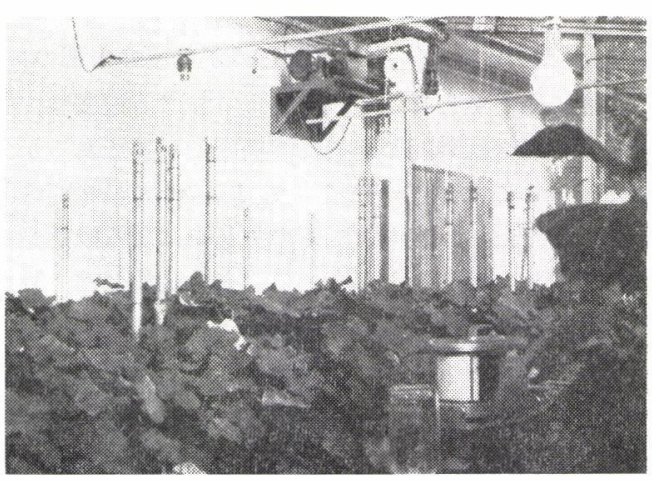

図 19 自然光線室内, 部屋の中央に自記記録計

器に $1 つ$, 計 $5 つ) に$ 継続的に加光られるインパルスに よって活動する。調節器の軸にとりつけられた特別な形 をもつ一連のカムは, 適当な值の抵抗衝きかける。こ れらの抵抗は，コントロールのゾンデを通ってきた電流 を選別し, 選別された電流は, 分離継続器の仲介でかな り長い持続をすつインパルスの形となって, 各モーター に振り向けられる。十あるいは一にしろ、インパルスは それぞれのモーターをかなり急速に開放または閧鎖の正 しい方向に回転させ，要求ど叔りの径衡を確立する.

6. 暗室の照明

温室は自然光で照明されるが，人工照明室の場合は，

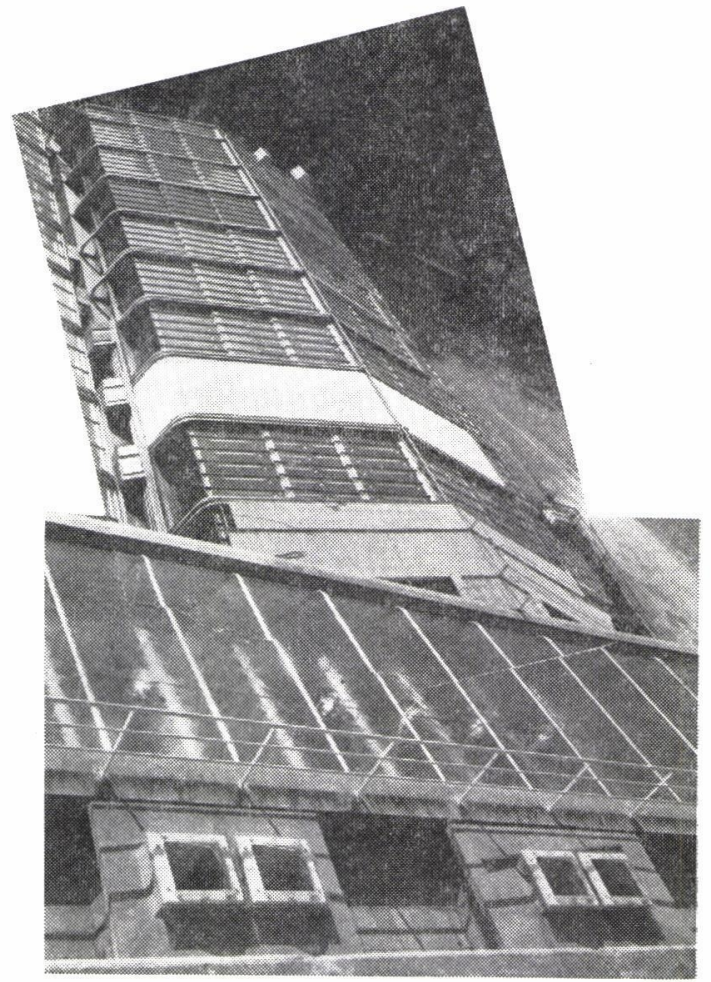

図 21 研究所の屋上より水を流している Phytotron の屋根と, 一部分日覆 をしたスーパー温室

Environ. Cont. in Biol. (生物環境調節) 
高性能の人工照明装置を設置せるねばならない。さらに， 必要に応じてその光線を質的にも是的にも随意傡える ことができるようにしなければならない，光線の質を変 えたいときは、ランプを取りかえ，量を变えたいときは， ランプの点滅による、遠隔制御盤に上って, 装着された 2, 688 個のランプを，それぞれ別個に思いの先に点隇 させることができる（図 14）。

部屋の照明は，普通それぞれ䄷いたアルミニウムの反 射装置のついた天井に取りつけられた䖝光管によってな される，この反射装直は特別の形の枠の中に収ってい る。幅 $1 \mathrm{~m}$, 長さ $1.5 \mathrm{~m}$ の各枠には, 色度昼光色デラッ クスで, $120 \mathrm{~W}$ の螢光管 16 個と, 低電圧で 5 点型に取 りつけられた $15 \mathrm{~W}$ の小さな自熱ランプ 43 個が含まれ ている(図 15, 16).

〔注〕 1961 年時に扔いて, 昼光色デラックスの䖝光 管と白熱灯の組み合わせは，スペクトル的な観点から みると，申し分のない取り合わせであった。事実，昼 光色デラックス管は青色光を豊富に放射し, 赤色光の

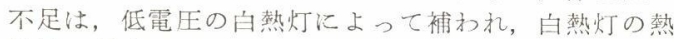
効果は最大限にさけられた。現代の技術は不幸に乙 て, いまだ生物学者の要求を満たしてくれていない。

部屋の真上に位置している中 2 階は，室内で行なわれ ている研究作業を冻げることなく，管を容易に取り代え

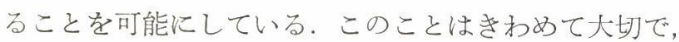
将来の照明技術の進歩に順応するためと, 今後の装置改 善を可能にするものである.

\section{7. 自然光線室の日長調節}

自然光線室の日長調節は，図 17,18 にみられるよう に, 二重ガラスの間沈から上へ巻上げるアルミニウム・ サッシの日覆によっている.オートマチックに電動で行 なわれるが，手動も可能である、室には白熱灯もある。

なお自然光線室に打ける regulator の類は, 壁でな く部屋の中央の台に取りつけて出り，自記記録計もそこ に置いて岕った（図 19）。廊下側の壁には，色分けされ た 3 つの蛇口があり, 水, 肥料, air が供給される.

\section{8. スーハーー温室（補助温室）}

Phytotron 研究所には, phytotron の補助温室ともい うべきスーパー温室と称するすのが 2 棟ある(図 20).

機能面からいらと semi-phytotron に近いもので, 空調 器によって温度の及の調節をしているが，床面吹出しで はない，屋根には，アルミニウム・サッシの日長調節の ための日覆がついている(図 21)。植木鉢もここでは砂 が用いられており，発芽したばかりの幼植物に時間点水 が行なわれていた。

\section{Phytotron 研究所の人員構成之機械の保守管理}

当研究所の所長は当初よりシュアール氏で, 副所長が ニッチ博士である。筆者が訪れたときは、研究者は 20 名 ということであった（京大小西通夫博士は筆者が訪祊る

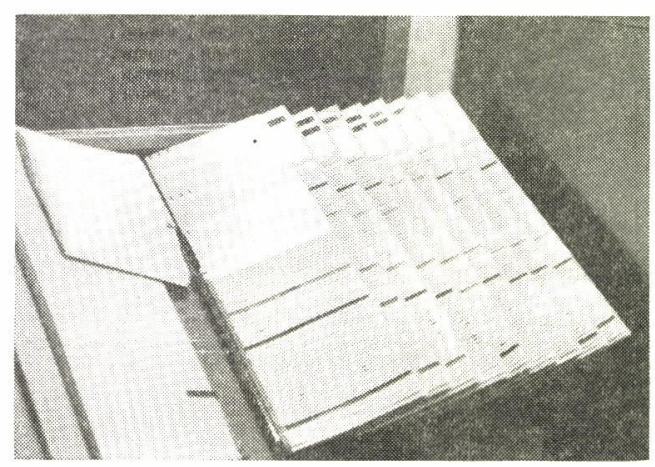

図 22 Phytotron の使用カード・ファイル（管理室）

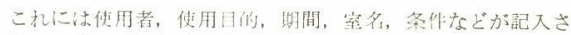

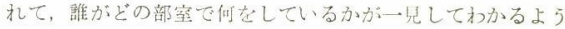
になっている

5 カ月ほど前に行かれて, 28 名と報告されている，海外 からの研究者などもいるので，かなり異動は多いものと 想像される)。この研究所では，他でみられるような部 制，研究空制をとっでらず，研究者が個人個人で，出 るとさにはテーマによってチームを作り，自由な立場で 研究が行なわれている、機栈技術者，テクニシャン，工 作室の技能者，園丁なぞを含めて 80 名以上，それに事 務, 写真技師, 小使などが若干名, 総勢 110 名内外の研 究所で，決して大きい研究所ではなく，むしろ小じんま りした研聟所といらべきであうら。わが国の phytotron と比較して，機栈技術者，テクニシャンを多数庸してい ることは，羡しい限りであった～

なお，参考までに，CNRS の研究者の等級拈よびサ ラリーを表 5 亿揭げておこう。

CNRS (文部省科学研究本部) 英下の研究所について は, Directeur, Maitre, Chargé, Attaché agrégé, Attaché non agrégé の 5 階級江分かれ, そのほが Stagiaire agrégé と Stagiaire non agrégé とがある。後の 2 者は最高 2 年間まで, Attaché agrégé は6 年間まで, 例外的に 8 年の場合も出る。Chargé 以上は大体に煔い て永年雇用とのことで峁った。李た，地城手当や家族手 当のあるところなど，わが国似似ている。

20 名あまりの研究者が以上述べたよらな phytotron の諸施設を使用するわけであるが（図 22），原田氏の話 では，使用希崩を制限しなければならない上うなこと は、これまでには一度もなかったといらことである。な 小, 個人あたりの研究費浊, 当人の年間所得額が 1 つの 目安で自由に使えるし, stock room では 5 万円程度の もの要では個人の配虑で自由に使える。高価な機械器具 を購入したいときは，副所長室へ申出る。

機械の保守管理については年 1 回定期的にチェックを 行なら，人工光線室については, 絶光ず 1 室を予備的に 使用しながらチェックするので, 12 室のうち 11 室が常 


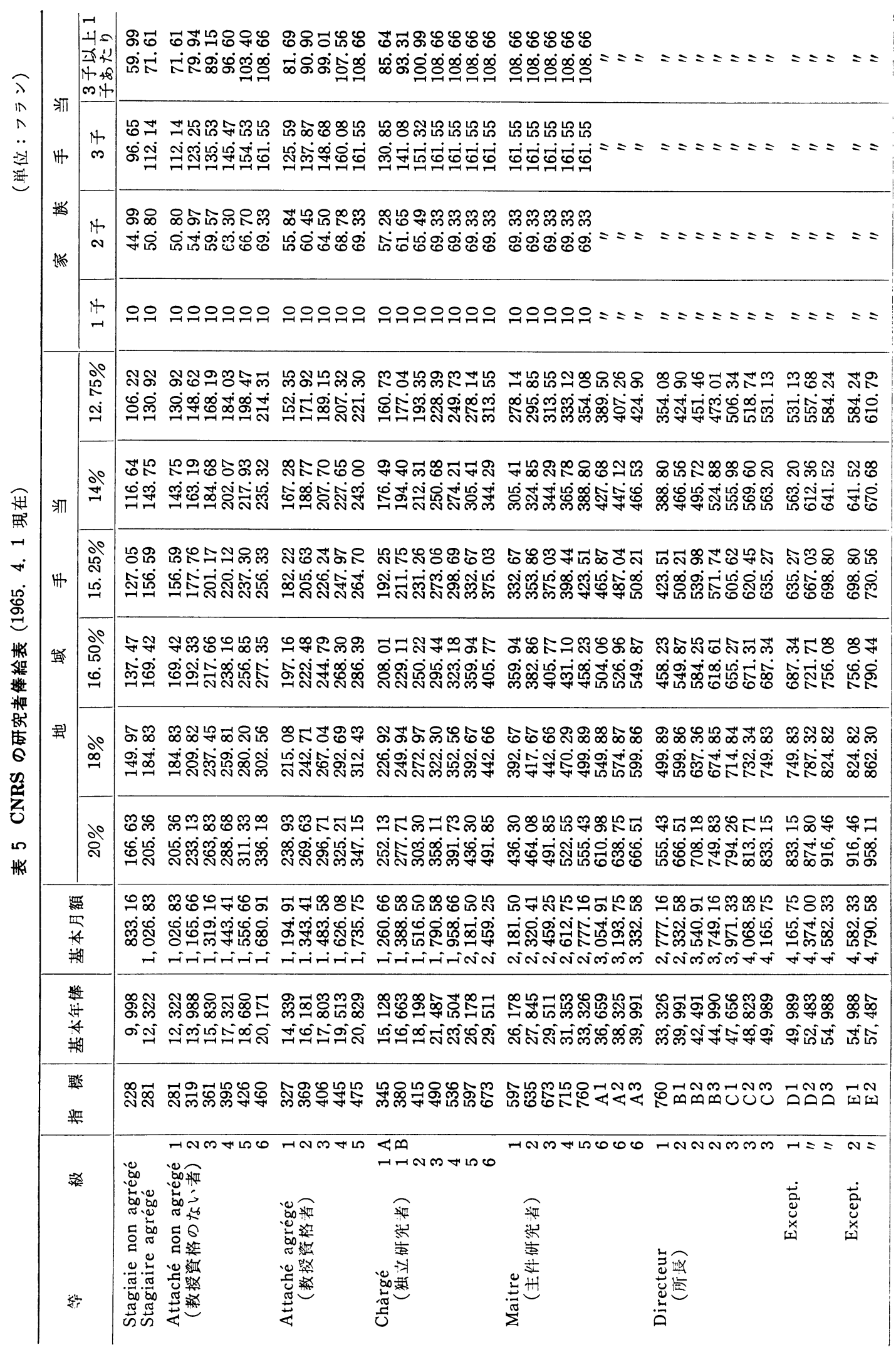


時運転されているわけである。

機械関係の事故は皆無といってよい，小さい故障は工 作室で直ちに修理できる，電力については，ときどき工 事のための停電があるが，それにもかかわらず自家発電 の装置がない、というのは, 日本と違って 3〜4 カ所の
会社から購入しているためである. 水については井水を 使用, heating についてはスチームを会社から購入して いる. 起こりやすい故障は, 暗処理シャッター, conditioner, 人工光線窒の明暗の切換えなどで女る.

\section{投 稿 規 定}

1. 本誌は日本生物環境調節研究会の機関誌で生物学 領域に打汀る環境調節に関心をもつ研究者, 技術者尔 よび学生を対象とし, 研究, 技術の新しい知識, 情報 を提供する目的で企画されたもので, 内容は総説, 原 著, 資料, 紹介, 講座, 寄書, 抄録, 新刊紹介, 雑記 事（研究会報告, ニュースなど）とし, 原則として和 文とします.

2. 原稿の執筆依頼, 送付原稿の採否などは編集委員 会に括いて行ないます. 原稿の登載順序, 体裁などの 決定は編集幹事に一任願います.

3. 昭和 40,41 年度の編集委員は次の通りです.

幹事 阪本寧男 (遣伝研)

委員 藤井利重 (東京教育大農), 福島 栄二(九大 農), 亀高正夫 (東大農), 小林陽太郎 (公衆 衛生院), 松村清二 (遺伝研), 宮山平分郎 (文部省), 尾田義治 (東北大農研), 立花一 雄 (東大農), 塚本洋太郎 (京大農), 八巻敏 雄 (東大教養), 山崎博男 (東京医歯大)

4. 総説, 原著, 資料, 紹介, 講座などの原稿は次の よらな体裁にしてください。

1) 記述は表題, 著者名, 所属执よびその所在地, 本文, 謝辞, 文献の順序とします，原著にはなるべく 英文の摘要をつける.

2) 原稿はB 4 版 400 字詰原稿用紙を用い, 平かな 左横書き, 楷書とし, 学術用語以外は原則として当用 漢字を用いる. 一般に通用している物質名, 術語など はなるべく和文を用いること、また英文の表題，著者 名, 所属初よびその所在地をタイプしたものをかなら ずつける。

3）生物の学名は,イタリック体（字の下に線を引 く）, 和名はカタカナで書き, 地名と外国名は原名を あげ，姓をスモール・キャピタル体（字の下に 2 本線 を引く）とすること.

4) 単位は原則として C.G.S. 単位を用いること. $\mathrm{km}, \mathrm{m}, \mathrm{cm}, \mathrm{mm}, \mathrm{m} \mu, \mathrm{A} ; \mathrm{m}^{2}, \mathrm{~cm}^{2} ; \mathrm{m}^{3}, l$, $\mathrm{cc}, \mathrm{ml}, \mathrm{mm}^{3} ; \mathrm{kg}, \mathrm{g}, \mathrm{mg}, \mu \mathrm{g} ; \mathrm{N}$ (規定), $\mathrm{pH}, \mathrm{ppm}, \operatorname{mol}$ (モル), $\mathrm{M}$ (モル濃度), $\mathrm{R}_{\mathrm{f}}$; $\mathrm{V}, \mathrm{mV}, \mathrm{A}, \mathrm{mA}, \mathrm{W}, \mathrm{kW}$; kcal, cal; ${ }^{\circ} \mathrm{C},{ }^{\circ} \mathrm{F}$, ${ }^{\circ} \mathrm{K}$ (絶対温度), $\mathrm{yr}, \mathrm{d}, \mathrm{hr}, \mathrm{min}, \mathrm{sec} ; \mathrm{mmHg}$, atm.
5）図括よび表の挿入箅所は本文中に明示し, 説明 はなるべく英文とする，図と写真は，原図を用いるこ と. 設計図などは都合によって委員会でトレースする ことがある。

6)引用文献は本文中の該当事項の右肩に(1)(2) の ごとく通し番号をつけ, 論文の最後に $\mathrm{ABC}$ 順に列記 すること.

(例) Went, F. W. and Cosper, L. 1945 Plant growth under controlled conditions. VI. Comparison between field and air-conditioned greenhouseg culture of tomato.

Amer. Jour. Bot. 32 : 643-654.

小熊桿 1954 生物の形質決定に関する遣伝 対環境の研究, 学術月報, 6:316-322.

Schmabe, W.W. 1957 The study of plant development in controlled environments. In Control of the Plant Environment (J. P. Hudson, ed.). Butterworths Sci. Publ., London : 16-35.

7）脚注はできるだけさけることを原則とし，やむ をえず脚注を要するばあいは, 本文の下欄に横線を引 き，その下に*,**などとして脚注を書くこと.

8) 次の語はかな書きとすること.

在, 有, 言, 一旦, 今, 色々, 所謂, 得, 於, 各 々, 凡, 及, 拘, 且, 必, 可成, 位, 茲, 此処, 殊, 事, 此, 之等, 支差, 双, 更, 併, 而, 霬々 直, 已, 即, 総, 其処, 其, 夫々, 大変, 沢山, 唯, 只, 但, 為, 丁度, 就, 時, 時々, 特, 所, 共, 乃至, 尚, 仲々, 就中, 乍, 等, 並, 成, 筈 甚, 再, 殆, 程, 略, 先, 又, 未, 全, 盡, 看做 若, 勿論, 持, 最, 元, 様, 漸, 依, 判, 分, 訳 僅, 亘, 我々, 吾々, 如, 出来.

5. 校正は初校のみを著者に弥願いします，指定され た期日までに確実に返送してください。

6. 別刷は 50 部（表紙なし）を著者に贈呈し, それ 以上別刷を希望するときは実費を徵集します．別刷希 望部数は研究会寄贈の 50 部を含めた総部数を著者校 正の際に打申込みください.

7. 原稿の送付括よび, 校正刷の返却, その他編集に ついての問合わせは下記にしてください.

静岡県三島市谷田 1,111

国立遣伝学研究所阪本寧男

原稿の募集：会員のみなさまからの投稿をお願いします. 